DOI: 10.12731/wsd-2018-5-28-45

УДК 616.715

\title{
ЭКСПЕРИМЕНТАЛЬНОЕ ЗАМЕЩЕНИЕ КОСТНЫХ ДЕФЕКТОВ МОЗГОВОГО ЧЕРЕПА С ИСПОЛЬЗОВАНИЕМ ТОНКОПРОФИЛЬНОГО НИКЕЛИДА ТИТАНА
}

\author{
Радкевич А.А., Гюнтер В.Э., Каспаров Э.В., Пуликов А.С., \\ Перетятько О.В., Мамедов Р.Х., Синюк И.В., Кауниетис С.М., \\ Подгорный В.Ю., Журавлева Т.Б.
}

Цель. Разработка новой медицинской технологии хирургического устранения дефектов костей мозгового черепа с использованием материалов с памятью формьл.

Методика. Экспериментальное замещение костных структур мозгового черепа выполнено на 69 беспородных кроликах в возрасте 1-1,5 лет. Дефекты создавали искусственно путем симметричного иссечения костной ткани в теменных и височных областях размером 15,0×15,0 мм без нарушения цеелостности твердой мозговой оболочки. Для устранения полученных дефектов применяли тонкопрофильный сверхэластичный сетчатьй никелид титана толщиной 40, 60 и 90 мкм помещенный в один, два и четыре слоя. $B$ иелях морфологического изучения материал забирали на 7, 14, 21, 28 и 35-е сут. В каждом варианте выполнено 3 серии опьттов (всего 135 с учетом кратности забора материала для гистологических исследований). Контролем служили 3 аналогично образованных изъяна, оставленных без замещения.

Результаты. Установлено, что оптимальная структура регенерата получена в результате применения в качестве имплантационного материала четьрехслойной сетчатой структуры, изготовленной из нити толщиной 40 мкм. В толще наружных слоев получена органотипичная пластинчатая и губчатая костная ткань, в толще внутренних слоев - плотная полуоформленная соединительная ткань. Образованный в этих случаях единый с имплантационным материалом регенерат дает возможность в полной мере восстанавливать анатомические и функииональные особенности костных структур мозгового черепа, твердой мозговой оболочки и головного мозга. Изучение прочессов остеогенеза в зависимости от толщины нитей, из которых был изготовлен имплантационный материал, не вылвил существен- 
ных отличий. Полученные результаты позволяет рекомендовать внедрение разработанной технологии в широкую клиническую практику.

Ключевые слова: никелид титана; костные дефекты свода черепа; остеогенез.

\title{
EXPERIMENTAL REPLACEMENT OF BONE DEFECTS OF CEREBRAL CRANIUM WITH FINE PROFILE TITANIUM NICKELIDE
}

\author{
Radkevich A.A., Gunter V.E., Kasparov E.W., \\ Pulikov A.S., Peretyatko O.V., Mamedov R.Kh., Sinyuk I.V., \\ Kaunietis S.M., Podgorniy V.Y., Zhuravleva T.B.
}

Purpose. Development of a new medical technology for surgical removal of defects in the bones of the brain skull using materials with shape memory.

Method. Experimental replacement of bone structures of the brain skull was performed on 69 mongrel rabbits aged 1-1,5 years. The defects were created artificially by symmetrical excision of bone tissue in the parietal and temporal areas of $15.0 \times 15.0 \mathrm{~mm}$ without disturbing the integrity of the Dura mater. To eliminate the obtained defects, a thin-profile superelastic titanium Nickel mesh with a thickness of 40, 60 and $90 \mu \mathrm{m}$ was used, placed in one, two and four layers. For morphological study the material was collected on day 7, 14, 21, 28 and 35. In each variant, 3 series of experiments were carried out (135 in total, taking into account the multiplicity of the material intake for histological studies). Controls were similarly educated 3 flaw left without replacement.

Results. It was found that the optimal structure of the regenerate was obtained as a result of the use of a four-layer mesh structure made of a $40 \mu \mathrm{m}$ thick thread as an implantation material. In the thickness of the outer layers, organotypic lamellar and spongy bone tissue was obtained, in the thickness of the inner layers - dense semi-formed connective tissue. Formed in these cases, a single regenerate with implantation material makes it possible to fully restore the anatomical and functional features of the bone structures of the brain skull, Dura and brain. The study of the processes of osteogenesis depending on the thickness of the threads from which the implant material was made did not reveal significant differences. The results obtained allow us to recommend the introduction of the developed technology in a wide clinical practice.

Keywords: titanium nickelide; bone defects of calvaria; osteogenesis. 


\section{Актуальность исследования}

Замещение костных дефектов человеческого тела остается одной из важных и сложных проблем современной медицины. Как показали многочисленные клинические наблюдения и экспериментальные исследования, костные дефекты (особенно кортикальных слоев) самостоятельно не восстанавливаются. Образование на их месте структуры, гистологически и функционально напоминающей костную ткань, возможно лишь после пластического замещения. Основными критериями успешности выполнения костно-пластических операций являются не только возобновление утраченной формы пораженной кости, но и восстановление функциональных возможностей органа за счет получения в костной ране органотипичного регенерата. Замещающий материал в этих целях должен создавать наибольшие благоприятные условия в зоне бывшего дефекта для развития новой костной ткани после вмешательства.

Для восстановления костных структур костей мозгового черепа широкое распространение получили реберные, подвздошные, расщепленные аутотрансплантаты костей свода черепа, титановые, корундовые имплантаты (монолитная алюмооксидная керамика), углерод-углеродный композиционный материал, полиметилметакрилаты, гидроксилапатиты и другие материалы, не проявляющие эффекта запаздывания [1-5, 8-14]. Однако данные материалы после помещения в тканевые дефекты резорбируются или ведут себя подобно инородным телам [7], что, несомненно, отрицательно сказывается на успехе операции.

Костным аутотрансплантатам для нормальной жизнедеятельности непосредственно после пересадки нужны кислород и питательные вещества и, в отличие от хрящевых, костные клетки не могут получить их диффузным путем. Нормальная жизнедеятельность аутокостной ткани в костных дефектах возможна лишь после восстановления сосудистой сети между трансплантатом и реципиентной зоной, что требует определенных временных затрат, в течение которых происходит гибель клеточных элементов трансплантата. Использование для костной пластики фрагментированных расщепленных трансплантатов позволило повысить эффективность данной категории операций, что связано с лучшими условиями и большей скоростью прорастания сосудов между частицами пересаженного материала. Однако, несмотря на это, подобные вмешательства сопровождаются гибелью остеоцитов в трансплантате, что сопровождается явлениями остеоцитарного остеолизиса и остеокластической резорбции, ведущих к уменьшению объема пересаженного трансплантата и формированием 
на основе оставшейся части регенерата по типу энхондральной оссификации. Последняя характеризуется образованием на месте разрушенных тканевых элементов трансплантата волокнистого или гиалинового хряща с последующей гибелью хондроцитов, обусловленной врастанием сосудов со стороны реципиентной зоны в толщу формирующегося регенерата. Одновременно с этим с краев костного дефекта за счет перицитов и остеогенных клеток костного ложа происходит образование остеобластической ткани, которая, в свою очередь, постепенно замещает деструированную хрящевую ткань новообразованной костной. Эти процессы требуют времени и значительных затрат энергетических ресурсов, в результате - уменьшение объема регенерата. Данное явление приемлемо к идеальным условиям, в которых протекают регенеративные процессы. Наличие гнойной инфекции, недостаточность кровоснабжения окружающих трансплантат тканей ведут к образованию в зоне дефекта тканей, далеких от органотипичных, причем их структура напрямую зависит от степени воздействия данных факторов на область оперативного вмешательства. В зонах плохого кровоснабжения, а, следовательно, и низкого парциального давления кислорода, преобладает образование соединительной (фиброзной) и хрящевой (а не костной) тканей [6].

Что касается применения вышеперечисленных имплантационных материалов, то отсутствие биохимической и биомеханической их совместимости с тканями организма ведет к их отторжению, либо в лучшем случае образованию грубоволокнистых соединительных тканей в зоне имплантации, по свойствам, далеким от свойств компактной и губчатой костной ткани. Данное обстоятельство обусловлено отсутствием гистерезисного поведения указанных имплантатов в условиях знакопеременной деформации, т.е. во время нагрузки и разгрузки в результате функционирования организма [7].

Целью настоящего исследования явилась разработка новой медицинской технологии хирургического устранения дефектов костей мозгового черепа с использованием материалов с памятью формы.

\section{Материалы и методы}

В целях повышения эффективности костно-реконструктивных операций на костях мозгового черепа использовали метод замещения дефектов сверхэластичным тонкопрофильным вязаным никелидом титана, имеющим сетчатую структуру, изготовленный из нити 40-90 мкм путем одинарного или двойного плетения (рис. 1). Материал разработан в НИИ медицинских материалов и имплантатов с памятью формы (г. Томск). 


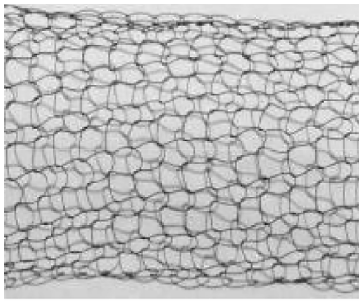

a

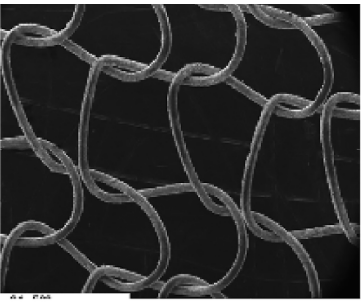

б

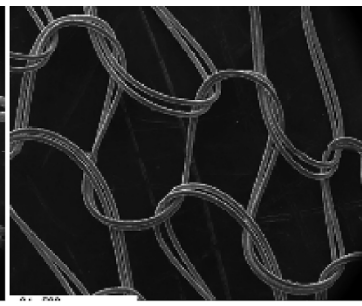

B

Рис. 1. Вязаный 40 мкм сетчатый никелид титана: а - общий вид; б - структура, изготовленная путем одинарного плетения; в - структура, изготовленная путем двойного плетения

Гистогенез репаративных процессов изучали на 69 беспородных кроликах обоего пола в возрасте 1-1,5 лет, которым после рассечения кожно-подкожно-мышечно-надкостничного слоя в теменной области вдоль срединно-сагиттальной плоскости и мобилизации указанных тканей в нижнелатеральном направлении образовывали по 2 костных дефекта в правой и левой височно-теменной областях во всю толщу костной ткани размером $15,0 \times 15,0$ мм с сохранением твердой мозговой оболочки. Последние замещали вышеуказанным материалом, изготовленным из нити различной толщины (40, 60 и 90 мкм) путем его помещения без натяжения между надкостницей и твердой мозговой оболочкой с наружным перекрытием на 3-5 мм в 1, 2, и 4 слоя с фиксацией с каждого края изъяна мини-фиксаторами из никелида титана с памятью формы в виде разомкнутого кольца, имеющими размеры в разомкнутом состоянии: основная длина $-6,3$ мм, ножки - 3,5 мм, изготовленными из проволоки диаметром 0,8 мм. Рану ушивали наглухо. В каждом варианте выполнено 3 серии опытов (всего 135 с учетом кратности забора материала для гистологических исследований). Контролем служили 3 аналогично образованных изъяна, оставленных без замещения.

Для изучения морфогенеза вновь образованной ткани забор материала проводили на 7, 14, 21, 28 и 35-е сут после имплантации. С этой целью повторно рассекали ткани в проекции дефекта, удаляли имплантационный материал вместе с вновь образованной тканью, которые подвергали гистологическим исследованиям. Тканевый материал фиксировали в 10 \% забуференном растворе формалина по Лилли. Если при визуальном и инструментальном осмотре предполагали костную ткань, то ее декальцинировали в 8 или $15 \%$ растворе азотной кислоты (в зависимости от 
зрелости). Срезы выполняли в верхне-нижнем направлении на всю глубину извлеченного материала из разных уровней (5 и 10 мм от костного края изъяна), выделяя, таким образом, 2 зоны - околодефектную и центральную. Материал заливали в целлоидин или парафин. Для количественно-морфологического исследования использовали обзорные срезы, окрашенные гематоксилином и эозином, более детализированную картину гистогенеза получали после селективной окраски препаратов по Маллори, Маллори-Гейденгайну и Шморлю.

Статистическая обработка полученных данных проводилась с использованием программного продукта «Statistica for Windows» версия 6.0 (StatSoft Inc., США). Результаты количественных показателей были представлены медианой (Ме) и интерквартильным размахом $(\mathrm{Q} 1-\mathrm{Q} 3)$. Достоверность различий количественных признаков анализировали с использованием критерия Н-критерия Крускала-Уоллиса при межгрупповом анализе. Статистически значимыми считали отличия при $\mathrm{P}<0.05$.

\section{Результаты исследования}

В процессе исследования выявлено, что благодаря тканевой диффузии сквозь сетчатый никелид титана в его толще образовывалась ткань, формирующаяся, вероятно, из клеток стромы миелоидной ткани прилежащих стенок каналов остеогенных клеток эндоста, тканей остеогенного слоя надкостницы и со стороны твердой мозговой оболочки, постепенно заполняя ячеистую структуру имплантационного материала, где подвергалась дальнейшей перестройке.

В семидневный срок в зоне бывших дефектов, замещенных 40 мкм имплантационным материалом в один слой, в околодефектной зоне в толще ячеистой структуры имплантационного материала определялась рыхлая, богато васкуляризированная соединительная ткань с большим количеством скоплений клеток фибробластического ряда. В некоторых участках коллагеновые волокна имели однонаправленность. Среди них встречались отдельные, овально вытянутые мелкие хондробласты. Глубже (между имплантационным материалом и твердой мозговой оболочкой) ткань была менее организованной. В центральной зоне сформированная ткань представляла собой рыхлую соединительную с тонкими волокнами, образующими крупноячеистую структуру. Ткань была бедна клеточными элементами, некоторые клетки напоминали ретикулярные с длинными отростками цитоплазмы, местами встречались скопления фибробластов, вокруг которых выявлялись коллагеновые волокна толщиной $\mathrm{Me}=2,9$ мкм 
(1,8-4,0 мкм). Единичные кровеносные сосуды относились к капиллярам и капиллярным щелям. Их диаметр составлял $\mathrm{Me}=5,1$ мкм (3,5-8,3 мкм)

Через 14 дней в околодефектной зоне происходило формирование уплотненной неоформленной соединительной ткани с извитыми коллагеновыми волокнами в виде тяжей и пучков толщиной $\mathrm{Me}=88,9$ мкм $(69,2-$ 101,4 мкм), имеющих тенденцию к определенному направлению (рис. 2).

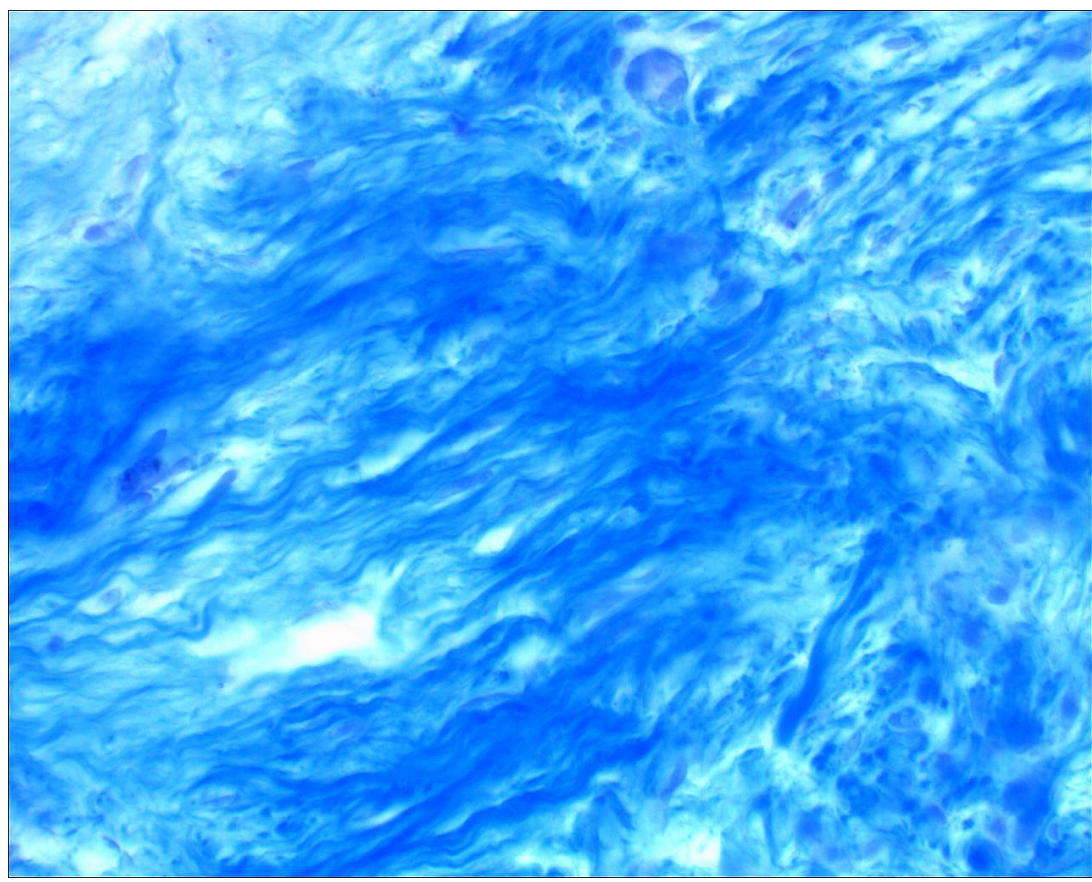

Рис. 2. Плотная полуоформленная соединительная ткань в толще имплантационного материала, 14 сут, окраска по Малори, ув.× 400

Ткань богата клеточными элементами. Между пучками коллагеновых волокон встречались единично расположенные крупные хрящевые клетки, локализовавшиеся в расширенных лакунах. Ближе к костному краю дефекта наблюдали вытянутые и мелкие хондроциты (до 5,0\% объема ткани). В некоторых участках выявлялись лакуны с двумя хрящевыми клетками. Несколько снижалась эозинофилия коллагеновых волокон. Количество сосудов уменьшилось. Данная картина характерна для начала формирования волокнистого хряща. В центральной части имплантата наблюдалась ткань, 
покрытая слоем плоского эпителия, имеющего, вероятно, эндотелиальное происхождение, толщиной Ме=7,2 мкм (6,8-8,9 мкм), под которым находилась рыхлая соединительная ткань, богатая клеточными элементами, с ядрами округлой и вытянутой формы и нежной слабоконтурируемой цитоплазмой. Клетки напоминали фибробласты. Встречались молодые клетки, принадлежность которых трудно определить. Под эпителием локализовалось большое количество сосудов микроциркуляторного русла диаметром Ме=9,1 мм (6,2-13,0 мкм). В этот срок коллагеновые волокна становились более толстыми и извитыми, и все больше приобретали направление, параллельное имплантационному материалу. Среди сосудов, помимо капилляров, встречались артериолы и венулы диаметром $\mathrm{Me}=78,8$ мкм (72,4-90,6 мкм) и Ме=38,9 мкм (20,1-45,5 мкм) соответственно. Под имплантационным материалом располагалась полуоформленная соединительная ткань с широкими капиллярами и отдельными артериолами. В некоторых сосудах определялись клетки крови миелоидного и лимфоидного ряда на разных стадиях развития.

К 21 суткам в ячеистой структуре имплантационного материала ближе к краю дефекта волокнистый хрящ замещался гиалиновым: коллагеновые волокна или исчезали, или становились слабо окрашиваемыми, хондроциты приобретали более округлую форму и выглядели крупнее. Межуточное вещество становилось более базофильным, что свидетельствовало о накоплении хондроитинсульфатов (рис. 3).

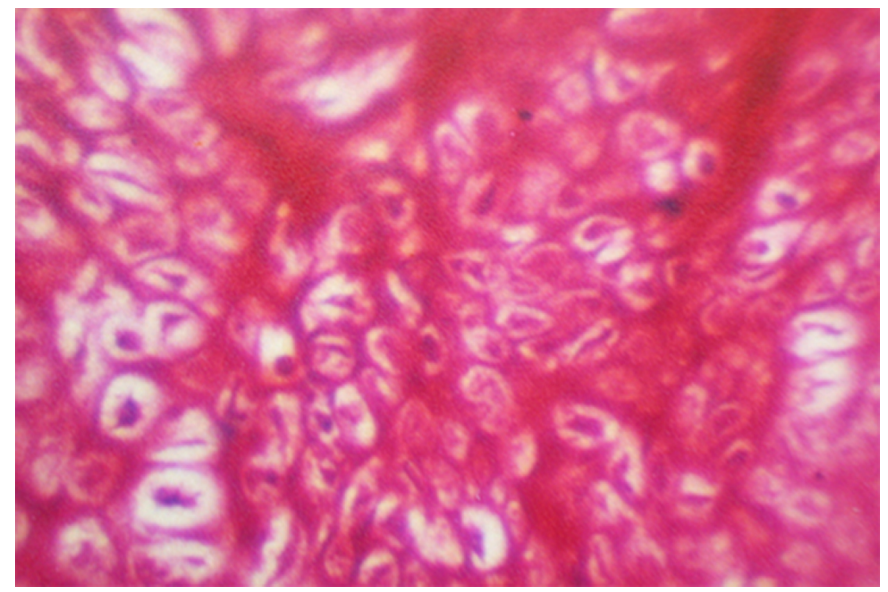

Рис. 3. Хондроциты в толще гиалинового хряща в наружных слоях имплантационного материала на 21 сутки, окраска по Шморлю, ув. $\times 400$ 
Среди хондрогенной ткани встречались участки остеогенеза с усиленной пикринофилией. Хондроциты местами располагались в виде монетных столбиков. Ближе к стенке дефекта выявлялись участки костной ткани, имеющие крупные сосуды и островки гиалинового хряща с оссификацией, увеличивалось количество пикринофильного оссеина, крупные пучки которого располагались не упорядочено. Наблюдалось много крупных, малоотростчатых остеоцитов. На границе с хрящом находились малодифференцированные клетки, похожие на остеобласты. Данная ткань напоминала грубоволокнистую костную. В некоторых участках среди островков хрящевой, выявлялась незрелая губчатая костная ткань с большим количеством крупных кровеносных сосудов, вокруг которых формировались за счет эндоста костные пластинки, имеющие концентрическое направление и напоминающие структуру остеона. Выявлялись плоские остеоциты с многочисленными отростками, направленными в сторону костных полостей с миелоидной тканью и навстречу друг другу, последние связывали несколько прилежащих клеток. В отдельных местах встречались участки костных параллельных пластинок, похожие на трабекулы. По своему строению и упорядоченности полученная ткань характеризовалась как пластинчатая и зрелая губчатая костная. В средней зоне среди нитей имплантационного материала сформированная ткань была представлена в основном волокнистым хрящом с редкими участками начала формирования гиалинового. Между ячейками имплантационного материала и твердой мозговой оболочкой наблюдалась плотная полуоформленная соединительная ткань с однонаправленным расположением извитых пучков коллагеновых волокон, имеющих диаметр Ме=136,4 мкм (84,5-148,1 мкм), являющийся большим относительно 14 суток $(\mathrm{P}<0.05)$.

На 28 сутки эксперимента среди ячеек имплантационного материала в околодефектной зоне ближе к надкостничному слою вдоль всей поверхности сформировалась пластинчатая костная ткань с отдельно расположенными мелкими остеоцитами, расположенными в лакунах. Непосредственно под имплантационным материалом находилась ткань, характеризующаяся наличием в ее толще трабекул, с выявлением между которыми костномозговых полостей, заполненных миелоидной тканью. Со стороны миелоидной ткани, вдоль костных трабекул, располагались остеогенные клетки в 1, реже в 2 ряда. Вокруг мелких кровеносных сосудов формировались структуры, похожие на остеоны, составляющих в длину $\mathrm{Me}=16,4$ мкм (15,2-20,1 мкм). Данная картина характерна для процесса активного формирования и созревания пластинчатой и губчатой костной ткани. В центральной зоне в ука- 
занном слое в толще костных трабекул, в некоторых местах, встречались островки гибнущей хрящевой ткани с нечеткими клеточными границами, пикнозом ядер и лизисом клеток. Костные пластинки имели различную степень тионинпикринофилии. Промежутки между трабекулами были выполнены миелоидной тканью. Ближе к твердой мозговой оболочке определялась сформированная плотная полуоформленная соединительная ткань с менее извитыми, в сравнении с предыдущим сроком, однонаправленными коллагеновыми пучками диаметром Ме=187,6 мкм (144,4-196,9 мкм), который достоверно увеличивался относительно аналогичных показателей на 14 и 21 сутки эксперимента $(\mathrm{P}<0.05)$.

Спустя 35 суток внутри имплантата во всех зонах определялась пластинчатая и зрелая губчатая костная ткань с выраженными костными пластинками в трабекулах и различной степенью пикринофилии. Миелоидная ткань заполняла промежутки между костными балками и была насыщена клетками крови, находящимися на разных стадиях дифференцировки. Ближе к твердой мозговой оболочке сформированная ткань не претерпевала дальнейших изменений.

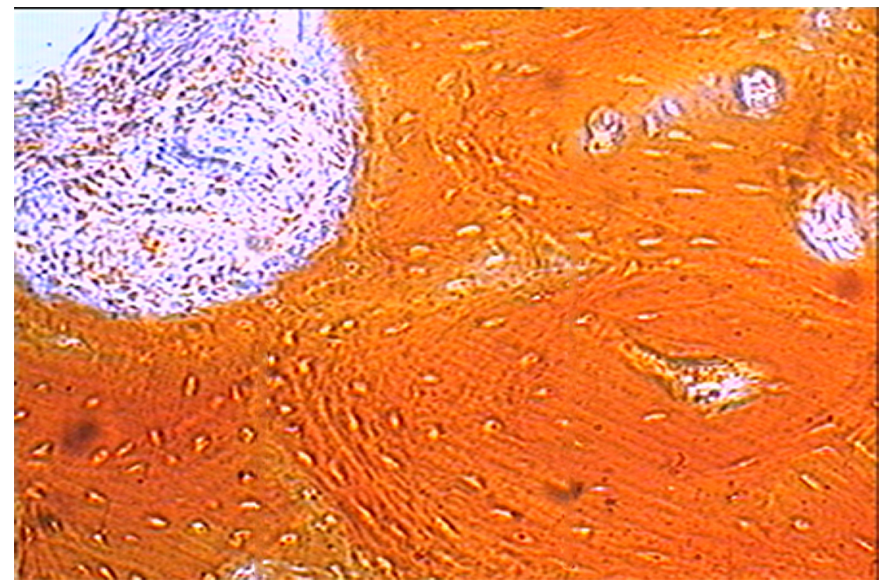

Рис. 4. Зрелая костная ткань в толще наружных слоев имплантационного материала на 35 сутки, окраска по Шморлю, ув.× 400

Изучение процессов остеогенеза в зависимости от толщины нитей, из которых был изготовлен имплантационный материал, не выявил существенных изменений. Что касается вариантов использования числа слоев замещаемого материала, то описанные процессы после однослойного 
замещения полностью соответствовали двуслойному. Четырехслойное замещение костных изъянов характеризовалось формированием преимущественно в те же сроки в толще наружных имплантационных слоев зрелой губчатой и пластинчатой костной ткани (рис. 4), а в толще внутренних - плотной полуоформленной соединительной ткани в течение 3-х недель согласно ранее описанным закономерностям (рис. 5).

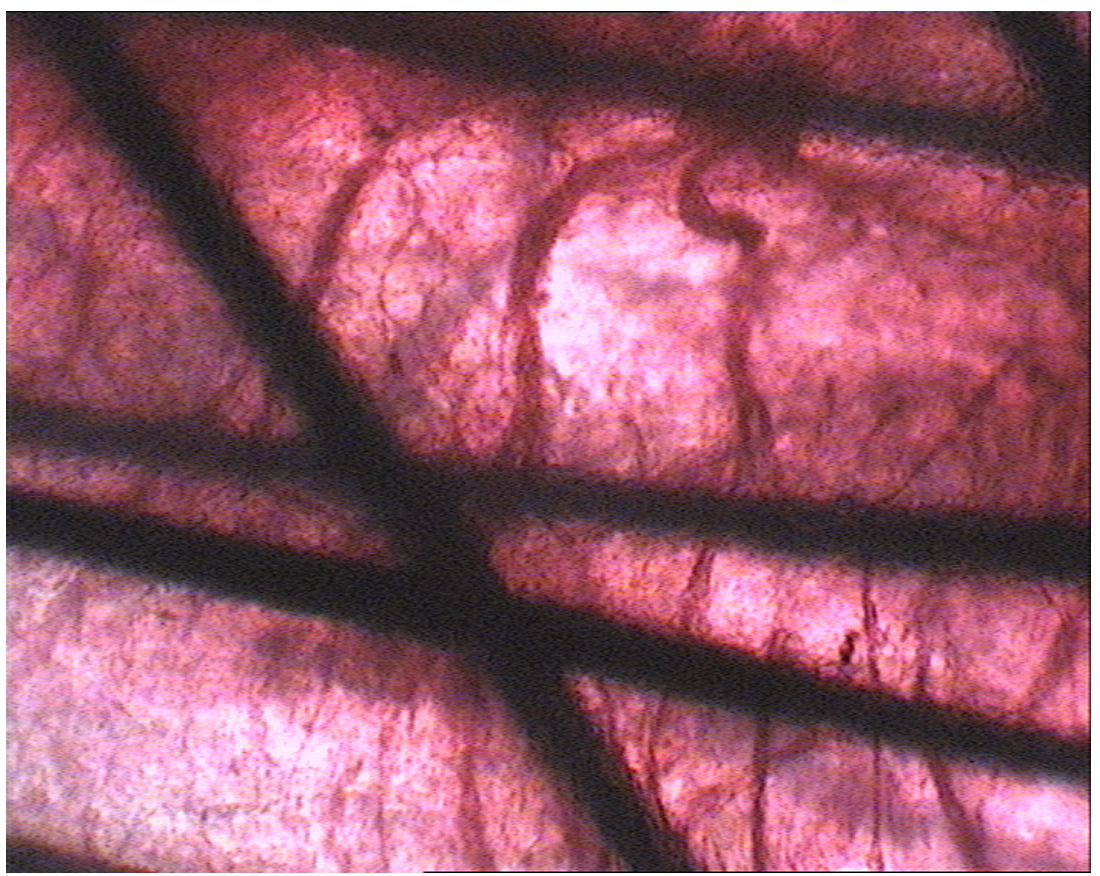

Рис. 5. Обзорный срез. Плотная полуоформленная соединительная ткань в толще имплантационного материала, 21 сут, гематоксилин и эозин, ув. $\times 400$

В группе контроля в дефектных зонах образования костной ткани не наблюдалось. Определялось сращение кожных покровов с твердой мозговой оболочкой с образованием между ними тонкослойной грубоволокнистой фиброзной ткани к 21 суткам эксперимента.

\section{Заключение}

Тонкопрофильный вязаный сетчатый никелид титана с высокой эффективностью может быть использован для замещения костных дефектов свода 
черепа, что подтверждают проведенные экспериментальные исследования. Благодаря биохимической и биомеханической совместимости никелида титана с тканями организма, биологические ткани со стороны реципиентных областей прорастали сквозь ячеистую структуру имплантационного материала, образуя единый с последним органотипичный регенерат, вплотную прилегаемый к последнему, т.е. без фиброзной прослойки. Проведенные исследования показали, что образование костной ткани в толще имплантируемого материала протекало согласно закономерностям непрямого остеогенеза: в начале развивалась рыхлая, затем плотная полуоформленная соединительная ткань, далее на ее месте формировался волокнистый хрящ с последующей его заменой на гиалиновый, который в последствие уступал место грубоволокнистой и, в конце, зрелой губчатой и пластинчатой костным тканям, аналогичных строению плоских костей черепа. Со стороны твердой мозговой оболочки в ячеистой структуре внутренних слоев имплантата (3-4 слой) образовывалась плотная полуоформленная соединительная ткань, окончание формирования которой наблюдали через 3 недели (без наличия таковых данная ткань формировалась в течение 28 суток эксперимента). Указанная ткань, имеющая непосредственный контакт с твердой мозговой оболочкой, за счет большей эластичности (в сравнении с костными тканями), создает оптимальные условия для функционирования головного мозга, предотвращая излишнее его сдавление.

Следует отметить, что благоприятными условиями образования органотипичных собственных тканей в зоне тканевых дефектов свода черепа способствовали адекватные физико-механические характеристики применяемого имплантационного материала: заданный уровень пластичности, прочности и эластичности; соответствие гистерезисных свойств поведению биологических тканей; циклостойкость изгибным деформациям; высокая коррозионная стойкость в биологических средах; оптимальный интервал между соседними нитями, т.е. размер ячейки. Нить, из которой изготавливается вязаный материал, представляет собой композиционную структуру, включающую сердцевину из наноструктурного монолитного никелида титана и микро пористый поверхностный слой (5-10 мкм) оксида титана, что в сочетание с пластичностью волокон, вязкоэластичностью деформации вследствие изменения при деформировании фазовой структуры никелида титана и смещения петельной структуры на широком участке квазипластической деформации обуславливает высокую пластичность материала в целом, необходимую при манипуляциях им в специфических и стесненных условиях выполняемой хирургической операции. Присущие имплантацион- 
ному материалу капиллярных свойств и высокой степенью смачиваемости позволяет насыщать его нити антимикробными растворами путем замачивания и применять в условиях инфицированной раневой поверхности.

\section{Выводы:}

1. Оптимальные условия для репаративной регенерации и полноценного замещения дефектов костей мозгового черепа создает помещение в их зону тонкопрофильного сверхэластичного никелида титана из 40 мкм нити в четыре слоя.

2. В наружных слоях образуется компактная и губчатая костные ткани, в толще внутренних - плотная полуоформленная соединительная ткань.

3. Образованный в зоне бывших дефектах единый с имплантационным материалом регенерат дает возможность в полной мере восстанавливать анатомические и функциональные особенности костных структур мозгового черепа, твердой мозговой оболочки и головного мозга.

\section{Сиисок литературы}

1. Белимготов Б.Х. Аутокраниопластика при черепно-мозговой травме и заболеваниях костей свода черепа / Б.Х. Белимготов, А.М. Чочаева, И.Ч. Хупсергенова // ІІІ Съезд нейрохирургов России: тез. докл. СПб., 2002. С. 632-633.

2. Бельченко В.А. Реконструкция и эндопротезирование краев и стенок глазниц, костей свода черепа, верхней и средней зон лица // III Съезд нейрохирургов России: тез. докл. СПб., 2002. С. 634.

3. К вопросу о тактике хирургического лечения тяжелой сочетанной травмы, осложненной посттравматическим инфарктом мозга / А.О. Трофимов, С.К. Королев, А.Ю. Абашкин и др. // Медицинский альманах. 2013. № 1. С. 124-126.

4. Краниопластика дефектов костей с дифференцированным применением имплантатов / В.А. Пятикоп, И.С. Мороз, В.И. Тарасенко и др. // Украинский нейрохирургичесий журнал. 2011. № 3. С. 22-24.

5. Кубраков К.М. Реконструктивная аллопластика дефектов костей черепа титановыми имплантатами / К.М. Кубраков, П.Ю. Карпук, А.Ю. Федукович // Новости хирургии. 2011. № 1. С. 72-76.

6. Лаврищева Г.И. Морфологические и клинические аспекты репаративной регенерации опорных органов и тканей / Г.И. Лаврищева, Г.А. Оноприенко. М: Медицина, 1996. 208 с.

7. Медицинские материалы и имплантаты с памятью формы. Медицинские материалы с памятью формы. Т. 1 / В.Э. Гюнтер, В.Н. Ходоренко, Т.Л. Чекалкин и др. Томск: Изд-во МИЦ, 2011. 534 с. 
8. Реконструктивная хирургия дефектов черепа: клинические рекомендации / А.А. Потапов, А.Д. Кравчук, Л.Б. Лихтерман и др. М., 2015. 22 с.

9. Тихомиров С.Е. Изучение реакции мягких тканей на имплантацию полимера «Реперен» / С.Е. Тихомиров, С.Н. Цыбусов, Л.Я. Кравец // Нейрохирургия. 2012. № 3. С. 45-52.

10. Тихомиров С.Е. Использование минипластины из реперена для пластики небольшого дефекта свода черепа при удалении внутримозговых гематом // Современные технологии в медицине. 2015. № 2. С. 198-201.

11. Цех Д.В. Определение сроков вмешательств по закрытию дефектов свода черепа / Д.В. Цех, В.П. Сакович, М.М. Бухер // Гений ортопедии. 2011. № 1. C. 44-47.

12. Autologous cranial bone graft use for trepanation reconstruction / P.V. Worm, N.P. Ferreira, G. Finger et al. // J. Cranio-Max.-Fac. Surg. 2015. V. 43, № 9, pp. 1781-1784.

13. Merlino G. Role of systematic scalp expansion before cranioplasty in patients with craniectomy defects / G. Merlino, S. Carlucci // J. Cranio-Max.-Fac. Surg. 2015. V. 43, № 8, pp.1416-1421.

14. Miyake H.A New technique for cranioplasty with Lshaped titanium plates and combination ceramic implants composed of hydroxyapatite and tricalcium phosphate (Ceratite) / H.A. Miyake, T. Ohta, H. Tanaka // J. Neurosurgery. 2000. V. 46, pp. 414-418.

\section{References}

1. Belimgotov B.H., CHochaeva A.M., Hupsergenova I.Ch. Autokranioplastika pri cherepno-mozgovoj travme i zabolevaniyah kostej svoda cherepa [Autocranioplasty in traumatic brain injury and diseases of the bones of the cranial vault]. III Sezd nejrohirurgov Rossii: tez. dokl. [III Congress of Neurosurgeons of Russia: mes. report]. SPb., 2002, pp. 632-633.

2. Bel'chenko V.A. Rekonstrukciya i ehndoprotezirovanie kraev i stenok glaznic, kostej svoda cherepa, verhnej i srednej zon lica [Reconstruction and endoprosthetics of the edges and walls of the orbits, bones of the cranial vault, upper and middle zones of the face]. III Sezd nejrohirurgov Rossii: tez. dokl. [III Congress of Neurosurgeons of Russia: mes. report]. SPb., 2002. S. 634.

3. Trofimov A.O., Korolev S.K., Abashkin A.Yu. i dr. K voprosu o taktike hirurgicheskogo lecheniya tyazheloj sochetannoj travmy, oslozhnennoj posttravmaticheskim infarktom mozga [To the question of tactics of surgical treatment of severe concomitant injury complicated by post-traumatic cerebral infarction]. Medicinskij al'manah [Medical Almanac]. 2013. № 1. S. 124-126. 
4. Pyatikop V.A., Moroz I.S., Tarasenko V.I. i dr. Kranioplastika defektov kostej s differencirovannym primeneniem implantatov [Cranioplasty of bone defects with differentiated use of implants]. Ukrainskij nejrohirurgichesij zhurnal [Ukrainian Neurosurgical Journal]. 2011. № 3. S. 22-24.

5. Kubrakov K.M., Karpuk P.Yu., Fedukovich A.YU. Rekonstruktivnaya alloplastika defektov kostej cherepa titanovymi implantatami [Reconstructive alloplasty of cranial bone defects with titanium implants]. Novosti hirurgii [News of surgery]. 2011. № 1. S. 72-76.

6. Lavrishcheva G.I., Onoprienko G.A. Morfologicheskie i klinicheskie aspekty reparativnoj regeneracii opornyh organov i tkanej [Morphological and clinical aspects of reparative regeneration of supporting organs and tissues]. M: Medicina, 1996. $208 \mathrm{~s}$.

7. Gyunter V.EH., Hodorenko V.N., Chekalkin T.L. et al. Medicinskie materialy $i$ implantaty s pamyat'yu formy. Medicinskie materialy s pamyat'yu formy. T.1 [Medical materials and implants with shape memory. Medical materials with shape memory]. Tomsk: Izd-vo MIC, 2011. 534 p.

8. Potapov A.A., Kravchuk A.D., Lihterman L.B. et al. Rekonstruktivnaya hirurgiya defektov cherepa: klinicheskie rekomendacii [Reconstructive surgery of the skull defects: clinical guidelines]. M. 2015. 22 p.

9. Tihomirov S.E., Cybusov S.N., Kravec L.YA. Izuchenie reakcii myagkih tkanej na implantaciyu polimera «Reperen» [Study of the reaction of soft tissues to the implantation of the Reperen polymer]. Nejrohirurgiya [Neurosurgery]. 2012. № 3, pp. 45-52.

10. Tihomirov S.E. Ispol'zovanie miniplastiny iz reperena dlya plastiki nebol'shogo defekta svoda cherepa pri udalenii vnutrimozgovyh gematom [The use of mini plate from reperen for plasty of a small defect in the cranial vault when removing intracerebral hematomas]. Sovremennye tekhnologii v medicine [Modern technologies in medicine]. 2015. № 2, pp. 198-201.

11. Cekh D.V., Sakovich V.P., Buher M.M. Opredelenie srokov vmeshatel'stv po zakrytiyu defektov svoda cherepa [Determining the timing of interventions to close the defects of the cranial vault]. Genij ortopedii [The genius of orthopedics]. 2011. № 1, pp. 44-47.

12. Worm P.V., Ferreira N.P., Finger G. et al. Autologous cranial bone graft use for trepanation reconstruction. J. Cranio-Max.-Fac. Surg. 2015. V. 43. № 9, pp. 1781-1784.

13. Merlino G., Carlucci S. Role of systematic scalp expansion before cranioplasty in patients with craniectomy defects. J. Cranio-Max.-Fac. Surg. 2015. V. 43. № 8, pp. 1416-1421.

14. Miyake H.A., Ohta T., Tanaka H. New technique for cranioplasty with Lshaped titanium plates and combination ceramic implants composed of hydroxyapatite and tricalcium phosphate (Ceratite). J. Neurosurgery. 2000. V. 46, pp. 414-418. 


\section{ДАННЫЕ ОБ АВТОРАХ}

Радкевич Андрей Анатольевич, доктор медицинских наук, старший научный сотрудник

Научно-исследовательский институт медичинских проблем Севера ул. Партизана Железняка, 32, г. Красноярск, 660022, Российская Федерачия radkevich.andrey@yandex.ru

Гюнтер Виктор Эдуардович, доктор технических наук, профессор Научно-исследовательский институт медицинских материалов и имплантатов с памятью формы ТГУ

ул. 19 Гвардейской дивизии, 17, г. Томск, 634034, Российская Федеращчия

Gunther_47@mail.ru

Каспаров Эдуард Вильямович, доктор медицинских наук, профессор Научно-исследовательский институт медицинских проблем Севера ул. Партизана Железняка, 32, г. Красноярск, 660022, Российская Федераичия clinic@impn.ru

Пуликов Анатолий Степанович, доктор медицинских наук, профессор Научно-исследовательский институт медичинских проблем Севера ул. Партизана Железняка, 32, г. Красноярск, 660022, Российская Федерачия pulik_off@mail.ru

Перетятько Ольга Викторовна, младший научный сотрудник

Научно-исследовательский институт медицинских проблем Севера ул. Партизана Железняка, 32, г. Красноярск, 660022, Российская Федераиия peretyatkoolga@mail.ru

Мамедов Расим Халигович, аспирант

Научно-исследовательский институт медицинских проблем Севера ул. Партизана Железняка, 32, г. Красноярск, 660022, Российская Федераиия don.ras2012@mail.ru 


\section{Синюк Илья Васильевич, аспирант}

Научно-исследовательский институт медичинских проблем Севера ул. Партизана Железняка, 32, г. Красноярск, 660022, Российская Федерация sinyukiv@gmail.com

Кауниетис Софья Максимовна, клинический ординатор

Красноярский государственный медицинский университет им. проф. В.Ф. Войно-Ясенеикого

ул. Партизана Железняка, 1, г. Красноярск, 660022, Российская Федерачия

sonya_9529@mail.ru

\section{Подгорный Василий Юрьевич, аспирант}

Научно-исследовательский институт медичинских проблем Севера ул. Партизана Железняка, 32, г. Красноярск, 660022, Российская Федераиия impn@impn.ru

Журавлева Татьяна Борисовна, кандидат медицинских наук, ассистент кафедры стоматологии детского возраста Красноярский государственный медииинский университет им. проф. В.Ф. Войно-Ясенецкого

ул. Партизана Железняка, 1, г. Красноярск, 660022, Российская Федерачия kostyazhuravlev1964@mail.ru

\section{DATA ABOUT THE AUTHORS}

Radkevich Andrey Anatolevich, MD, Senior Researcher Research Institute of Medical Problems of the North 3g, Partizan Zheleznyak Str., Krasnoyarsk, 660022, Russian Federation radkevich.andrey@yandex.ru

Gyunter Viktor Eduardovich, Doctor of Technical Sciences, Professor Research Institute of Medical Materials and Implants with Form Memory, Tomsk State University

17, 19 Guards Division Str., Tomsk, 634034, Russian Federation gunther_47@mail.ru 
Kasparov Eduard Vilyamovich, MD, Professor

Research Institute of Medical Problems of the North

3g, Partizan Zheleznyak Str., Krasnoyarsk, 660022, Russian Federation clinic@impn.ru

Pulikov Anatoly Stepanovich, MD, Professor Research Institute of Medical Problems of the North

3g, Partizan Zheleznyak Str., Krasnoyarsk, 660022, Russian Federation pulik_off@mail.ru

Peretyatko Olga Viktorovna, Junior Researcher

Research Institute of Medical Problems of the North

3g, Partizan Zheleznyak Str., Krasnoyarsk, 660022, Russian Federation peretyatkoolga@mail.ru

Mamedov Rasim Khaligovich, graduate student

Research Institute of Medical Problems of the North

3g, Partizan Zheleznyak Str., Krasnoyarsk, 660022, Russian Federation don.ras2012@mail.ru

Sinyuk Ilya Vasilevich, graduate student

Research Institute of Medical Problems of the North

3g, Partizan Zheleznyak Str., Krasnoyarsk, 660022, Russian Federation sinyukiv@gmail.com

Kaunietis Sofya Maksimovna, Clinical Intern

Krasnoyarsk State Medical University

1, Partizan Zheleznyak Str., Krasnoyarsk, 660022, Russian Federation sonya_9529@mail.ru

Podgorny Vasily Yuryevich, Graduate Student Research Institute of Medical Problems of the North

3g, Partizan Zheleznyak Str., Krasnoyarsk, 660022, Russian Federation impn@impn.ru

Zhuravleva Tatyana Borisovna, Candidate of Medical Sciences, Assistant of the Department of Pediatric Dentistry Krasnoyarsk State Medical University

1, Partizan Zheleznyak Str., Krasnoyarsk, 660022, Russian Federation kostyazhuravlev1964@mail.ru 